J. Clin. Chem. Clin. Biochem.

Vol. 19,1981, pp. $249-258$

\title{
Monitoring of Therapeutic Serum Concentrations of Antiepileptic Drugs by a Newly Developed Gas Chromatographic Procedure and Enzyme Immunoassay (EMIT): A Comparative Study
}

\author{
By W. R. Külpmann and M. Oellerich
}

Technical assistance: K. Petry, L. Lütke-Holz and I. Isberner

Institut für Klinische Chemie (geschäftsf. Direktor: Prof. Dr. Dr. J. Büttner) der Medizinischen Hochschule Hannover

(Received July $7 /$ November 26,1980 )

Summary: A gas chromatographic procedure for the simultaneous determination of carbamazepine, phenobarbital and phenytoin using SP 2510 DA as stationary phase is presented. The antiepileptic drugs are determined simultaneously without derivatisation under isothermal conditions by a flame ionisation detector. The gas chromatographic procedure can be easily mechanized. The coefficient of variation for the precision from day to day is $8.9 \%$ for carbamazepine, $7.0 \%$ for phenobarbital and $4.3 \%$ for pheny toin as calculated from single determinations. The deviations from the target value of spiked pool sera range from 4.3 to $9.5 \%$. The gas chromatographic results of this method and of determinations by Dexsil 300 for primidone and SP 1000 for ethosuximide are compared with the corresponding enzyme immunoassays (EMIT). The precision of the gas chromatographic methods is somewhat better than EMIT. When patients' sera are analysed by both procedures the results show no clinically relevant differences. It can be concluded that the different methods are interchangeable and may be selected according to practical necessities.

\section{Kontrolle der therapeutischen Serumkonzentrationen von Antiepileptika mit Hilfe eines neuen gaschromatographischen Verfahrens und Enzymimmunotests (EMIT): Eine Vergleichsstudie}

Zusammenfassung: Ein gaschromatographisches Verfahren zur gleichzeitigen Bestimmung von Carbamazepin, Phenobarbital und Phenytoin an der stationären Phase SP 2510 DA wird beschrieben. Der Variationskoeffizient für die Präzision von Tag zu Tag beträgt bei Einzelbestimmungen 8,9\% für Carbamazepin, 7,0\% für Phenobarbital und 4,3\% für Phenytoin. Die Abweichungen vom Sollwert aufgestockter Proben schwanken zwischen 4,3 und 9,5\%. Die Methode zeichnet sich durch eine besonders gute Praktikabilität aus, da gleichzeitig 3 häufig verordnete Antiepileptika isotherm, ohne Derivatbildung gemessen werden können. Die Ergebnisse dieses gaschromatographischen Verfahrens, sowie die Rẽsultate der Primidonbestimmung an Dexsil 300 und der von Ethosuximid an SP 1000 werden mit den entsprechenden Enzymimmunoassays (EMIT) verglichen. Die Präzision der gaschromatographischen Methoden ist ähnlịch oder besser als von EMIT. Bei der Analyse der gleichen Patientenseren mit den verschiedenen Analysenverfahren finden sich gewöhnlich keine klinisch relevanten Unterschiede. Die Bestimmungen können also je nach den praktịschen Erfordernissen und apparativer Ausstattung wahlweise mit Hilfe der Gaschromatographie oder mittels EMIT durchgeführt werden.

\section{Introduction}

In general gas chromatographic procedures for the measurement of antiepileptic drugs are - though reliable less practicable than EMIT. In order to improve practicability we used the newly available stationary phase SP 2510 DA $(1,2)$ that allows the simultaneous determination of antiepileptic drugs without derivatisation under isothermal conditions - important prerequisites for a mechanization of gas chromatography. As EMIT analyses are in widespread use we were interested in the comparison of results obtained by these two procedures, to see if they are interchangeable (3-10). Identical values would mean that the methods could be selected according to practical necessities, different values that at least one method is less reliable. In order to enable a 
final conclusion on the diagnostic strategy using EMIT we decided to incorporate the comparison of results by gas chromatography and EMIT for ethosuximide and primidone.

\section{Material and Methods}

Gas chromatography

\section{Materials}

Carbamazepine (5H-dibenz[b, f]azepin-5-carboxamide (Geigy, D-7867 Wehr)

Ethosuximide (2-Ethyl-2-methylsuccinimide) (Parke, Davis \& Comp., D-8000 München)

2,2,3-Trimethylsuccinimide (Aldrich-Europe, D-4054 Nettetal)

Phenobarbital (5-Ethyl-5-phenyl-barbituric acid) Bayer, D-5090 Leverkusen)

Pheny toin (5,5-Diphenylhydantoin) (Desitin, D-2000 Hamburg)

Primidone (5-Ethyldihydro-5-phenyl-4, 6- $(1 \mathrm{H}, 5 \mathrm{H})$-pyrimidindione (Desitin, D-2000 Hamburg)

Carbamazepine-10, 11-epoxide (Geigy, D-7867 Wehr)

5-(4'-Methylphenyl) 5-phenylhydantoin ( $25 \mathrm{mg} / \mathrm{l}$ ) (Sigma, D-8028 Taufkirchen)

5-Ethyl-5-(4'-hydroxyphenyl)-barbituric acid (Aldrich-Europe, D-4054 Nettetal)

Phenyl-ethyl-malondiamide (ICI-Pharma, D-6831 Plankstadt)

5-(4'-Hydroxy phenyl)-5-phenylhydantoin (Desitin, D-2000 Hamburg)

The substances are dissolved in ethyl acetate/acetic acid $(100 \mathrm{ml}$ $+1 \mathrm{ml}$ ): $100 \mathrm{mg} / \mathrm{l}$. The solutions are stable for at least 3 months at $4^{\circ} \mathrm{C}$. The other drugs used for interference studies were obtained as gifts from the pharmaceutical manufacturers. The other chemicals were obtained from Merck, D-6100 Darmstadt. The organic solvents were distilled before use.

Stationary phases:

$3 \%$ SP 2250 DA on Supelcoport 100/120 mesh

$3 \%$ Dexsil 300 on Supelcoport $100 / 120$ mesh

$2 \%$ SP 2510 DA on Supelcoport 100/120 mesh

$1 \%$ SP 1000 on Supelcoport $100 / 120$ mesh

were purchased from Supelco, Bellefonto (USA).

Gas chromatography was performed using a Varian model 1440

(Varian, D-6100 Darmstadt) equipped with a flame ionisation detector.

\section{Procedure}

The determinations of the antiepileptics using SP 2250 DA, Dexsil-300 and SP-1000 were performed as described $(11,12)$.

In the cuse of SP 2510 DA the samples were prepared in the same manner as cited (11), but before extraction the internal standard 5-(4'-methylphenyl-5-phenylhydantoin) $(10 \mu \mathrm{g})$ was added. Gas chromatographic conditions: Oven $240^{\circ} \mathrm{C}$, inlet $265^{\circ} \mathrm{C}$, detector $265^{\circ} \mathrm{C}$; siliconised glass column (length: $0.90 \mathrm{~m}$, internal diameter: $2 \mathrm{~mm})$. Carrier gas $\left(\mathrm{N}_{2}\right)$ flow rate: $40 \mathrm{ml} / \mathrm{min}$, hydrogen $30 \mathrm{ml} / \mathrm{min}$, air $300 \mathrm{ml} / \mathrm{min}$.

\section{Enzyme immunoassay (EMIT) \\ Materials}

Reagents for the enzyme immunoassay were obtained from Syva, Palo Alto (USA) (distributed in W. Germany by E. Merck, D-6100 Darmstadt).

\section{Procedure}

The determinations were performed as previously described (5) using an Eppendorf analyzer 5010 (Eppendorf, D-2000 Hamburg). The results were calculated by on-line data processing using an empirical spline interpolation (13).

Specimen

Serum samples were obtained from patients under therapy with antiepileptics at our hospițal.

Control sera:

AED Antiepileptic drug control (Syva, Palo Alto, USA, distributed in W. Germany: Merck, D-6100 Darmstadt)

Biotrol-thérapeutique (Laboratoires Biotrol, Paris, France)

Ortho Anticonvulsant Control Serum (Ortho Diagnostics, Rari$\tan ($ USA)).

Statistics

The results obtained by gas chromatography and EMIT were compared by principal component analysis $(14,15)$ taking into account the imprecision of both methods. The correlation coefficient was calculated from the linear regression analysis, standard error as an estimate of random error according to l.c. (16). The significance of the difference between the means was determined by the sign test $(\alpha=5 \%)(17)$.

\section{Results and Discussion}

\section{Determination of carbamazepine, phenobarbital and phenytoin using SP $2510 \mathrm{DA}$}

\section{Precision}

Precișion in the series: $2 \mathrm{ml}$ of a drug-free serum is spiked with the antiepileptics to obtain concentrations in the therapeutic range. $1 \mathrm{ml}$ and $1 \mathrm{ml}$ are prepared separately and analysed by gas chromatography. The standard deviation is calculated according to l.c. (18). The coefficients of variation $(n=10)$ : Carbamazepine: $3.3 \%$, phenobarbital: $1.4 \%$, phenytoin: $1.9 \%$. Precision from day to day: Spiked pool serum and commercially available control sera were measured on 10 days. The coefficients of variation based on single determinations vary between 4.3 and $10.9 \%$ (tab. 1).

\section{Accuracy and specificity}

The deviation from the target values during these ten days was between -8.5 and $+9.5 \%$ (tab. 1). Interfering compounds from the serum matrix were not observed, apart from cholesterol, which inhibits the precise measurement of primidone. Typical gas chromatograms are given in figure 1 and 2.

A possible interference in the determination by other drugs was evaluated as follows: The compound, or, if not available, a tablet, was dissolved in $10 \mathrm{ml}$ ethyl acetate/acetic acid $(100 \mathrm{ml}+1 \mathrm{ml})$ at an amount of at least $1 \mathrm{~g} / 1$ presuming sufficient solubility. $2 \mu \mathrm{l}$ were injected into the gas chromatograph. In this way solubility and chromatographic behaviour of the drugs in relation to the antiepileptics and the internal standard are evaluated simultaneously. The exact concentration of the 
Tab. 1. Precision from day to day.

\begin{tabular}{|c|c|c|c|c|}
\hline & $\begin{array}{l}\text { Number } \\
\text { of deter- } \\
\text { mina- } \\
\text { tions } \\
\mathrm{n}\end{array}$ & $\begin{array}{l}\text { Mean value } \\
\bar{x}(\mu \mathrm{mol} / \mathrm{l})\end{array}$ & $\begin{array}{l}\text { Coeffi- } \\
\text { cient } \\
\text { of varia- } \\
\text { tion* } \\
\text { CV }(\%)\end{array}$ & $\begin{array}{l}\text { Deviation } \\
\text { from the } \\
\text { target } \\
\text { value } \\
\text { in } \%\end{array}$ \\
\hline \multicolumn{5}{|l|}{ Carbamazepine } \\
\hline $\begin{array}{l}\text { GC: Dexsil } 300 \\
\text { GC: SP } 2510 \text { DA }\end{array}$ & $\begin{array}{l}\left.13^{1}\right) \\
\left.10^{1}\right) \\
\left.10^{2}\right)\end{array}$ & $\begin{array}{l}22.7 \\
26.5 \\
34.9\end{array}$ & $\begin{array}{r}4.3 \\
8.9 \\
10.9\end{array}$ & $\begin{array}{l}+7.1 \\
+4.3 \\
+3.3\end{array}$ \\
\hline EMIT & $\begin{array}{l}\left.15^{2}\right) \\
\left.20^{3}\right)\end{array}$ & $\begin{array}{l}34.1 \\
25.4\end{array}$ & $\begin{array}{l}8.2 \\
6.4\end{array}$ & $\begin{array}{r}+0.7 \\
0.0\end{array}$ \\
\hline \multicolumn{5}{|l|}{ Ethosuximide } \\
\hline GC: SP 1000 & $\begin{array}{l}\left.10^{1}\right) \\
\left.10^{2}\right)\end{array}$ & $\begin{array}{l}350.2 \\
692.8\end{array}$ & $\begin{array}{l}2.6 \\
2.0\end{array}$ & $\begin{array}{l}-1.1 \\
-2.1\end{array}$ \\
\hline EMIT & $\begin{array}{r}\left.20^{3}\right) \\
\left.7^{2}\right)\end{array}$ & $\begin{array}{l}533.9 \\
753.2\end{array}$ & $\begin{array}{l}5.2 \\
4.9\end{array}$ & $\begin{array}{l}+0.5 \\
+6.4\end{array}$ \\
\hline \multicolumn{5}{|l|}{ Phenobarbital } \\
\hline $\begin{array}{l}\text { GC: SP } 2250 \text { DA } \\
\text { GC: SP } 2510 \text { DA }\end{array}$ & $\begin{array}{l}\left.13^{1}\right) \\
\left.10^{1}\right) \\
\left.10^{2}\right)\end{array}$ & $\begin{array}{r}86.1 \\
93.1 \\
173.4\end{array}$ & $\begin{array}{l}5.1 \\
7.0 \\
7.3\end{array}$ & $\begin{array}{r}0.0 \\
+8.0 \\
+0.6\end{array}$ \\
\hline EMIT & $\begin{array}{l}\left.20^{3}\right) \\
\left.20^{3}\right) \\
\left.20^{3}\right) \\
\left.20^{4}\right) \\
\left.20^{4}\right)\end{array}$ & $\begin{array}{r}44.8 \\
127.9 \\
210.2 \\
46.0 \\
229.7\end{array}$ & $\begin{array}{r}12.0 \\
7.8 \\
10.3 \\
8.6 \\
8.7\end{array}$ & $\begin{array}{l}+4.0 \\
+1.0 \\
+2.4 \\
+6.8 \\
+6.7\end{array}$ \\
\hline \multicolumn{5}{|l|}{ Phenytoin } \\
\hline GC: SP 2510 DA & $\begin{array}{l}\left.10^{1}\right) \\
\left.10^{2}\right)\end{array}$ & $\begin{array}{l}52.0 \\
72.5\end{array}$ & $\begin{array}{l}4.3 \\
4.3\end{array}$ & $\begin{array}{l}+9.5 \\
-8.5\end{array}$ \\
\hline EMIT & $\begin{array}{l}20^{3} \text { ) } \\
20^{3} \text { ) } \\
\left.20^{3}\right) \\
\left.20^{4}\right)\end{array}$ & $\begin{array}{l}38.0 \\
60.2 \\
60.2 \\
36.2\end{array}$ & $\begin{array}{r}12.9 \\
8.4 \\
4.1 \\
10.8\end{array}$ & $\begin{array}{l}-4.0 \\
+1.3 \\
+1.3 \\
-8.7\end{array}$ \\
\hline \multicolumn{5}{|l|}{ Primidone } \\
\hline GC: Dexsil 300 & $\left.13^{1}\right)$ & 24.2 & 7.5 & +5.7 \\
\hline EMIT & $\begin{array}{l}\left.20^{3}\right) \\
\left.20^{2}\right)\end{array}$ & $\begin{array}{l}55.4 \\
57.0\end{array}$ & $\begin{array}{l}4.8 \\
4.4\end{array}$ & $\begin{array}{l}+0.8 \\
+3.8\end{array}$ \\
\hline
\end{tabular}

GC: Gas chromatography Coefficient of variation in gas chromatography based on single determinations, in EMIT based on duplicates.

1) spiked pool serum

2) Ortho Anticonvulsant Control Serum

3) AED Antiepileptic Drug Control Syva

4) Biotrol-Thérapeutique I

drugs cannot be given, but it is in the toxic or lethal range:

Acetylsalicylic acid

Allobarbital,

Allopurinol

4-Aminophenazone

Amitryptiline

Amobarbital

Amphetamine

Ampicillin

Aprobarbital

Antazoline

Ascorbic acid

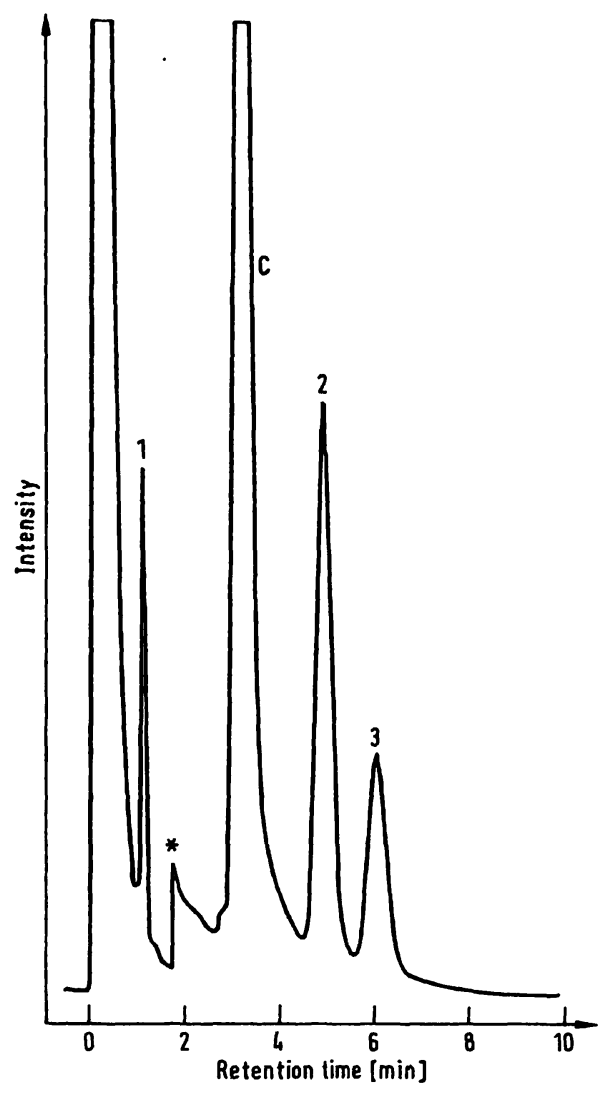

Fig. 1. Gas chromatogram of an extract of a serum obtained from a patient treated with phenobarbital and pheny toin.

1: Phenobarbital $(91.3 \mu \mathrm{mol} / \mathrm{l})$

2: Phenytoin $(91.2 \mu \mathrm{mol} / \mathrm{l})$

3: Internal standard

C: Cholesterol

*: 4-fold sensitivity

Barbital

Butalbital

Carbamazepine-10, 11-epoxide

Carbromal

Chlordiazepoxide

Chloroquine

Chlorpromazine

Chlorprothixene

Clomethiazole

Clonażepam

Codeine

Cyclobarbital

Dextromoramide

Diazepam

2,2-Diethylallylacetamid

Diphenhydramine

Doxepine

Ethinamate

5-Ethyl-5-(4'-hydroxyphenyl)-barbituric acid

Fenethylline

Fenfluramine

Fluphenazine

Furosemide

Gentamicin 
Glutethimide

Haloperidol

Heptabarbital

Hexobarbital

5-(4'-Hydroxyphenyl)-5-phenylhydantoin

Hyoscyamine-N-butylbromide

Imipramine

Indomethacin

Ketobemidone

Mebhydrolin

Meclizine

Mephenytoin

Methadone

Methamphetamine

Methaqualone

Methohexital

Methotrexate

Methsuximide

Methyldopa

Methyprylon

Morphine

Nicotineamide

Nitrazepam

Nitrofurantoin

Normethadone

Oxazepam

Oxyphenbutazone

Paramethadione

Pentobarbital

Phenyl-ethyl-malondiamide

Phenformin

Pheniramine-p-amino-salicylate

Phenprocoumon

Phenylbutazone

Prednisolone

Probenecid

Promethazine

Propallylonal

Prothipendyl

Pyrithyldione

Reserpine

Secobarbital

Sulfamethoxydiazine

Tetracycline

Thioridazine

Tolbutamide

Triflupromazine

Trimethadione

Valproate

Vinylbital .

Among the numerous substances tested only codeine in lethal concentrations could interfere with the determination of phenobarbital. In the future other drugs will be included in the evaluation, as well as their metabolites that are not easily available, and on the other hand not very likely to interfere because of their usually high polarity. But already - from the substances

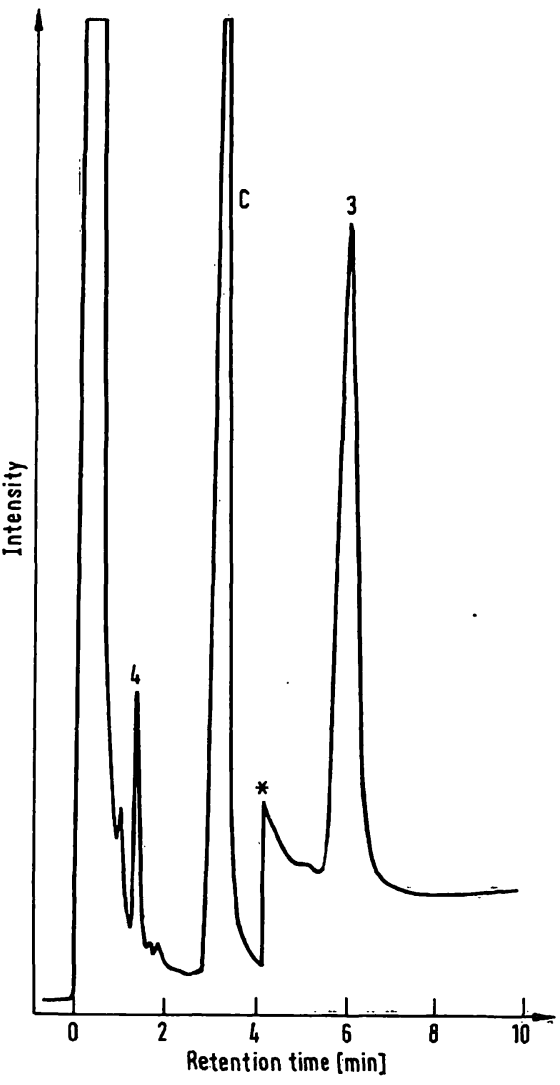

Fig. 2. Gas chromatogram of an extract of a serum obtained from a patient treated with carbamazepine.

4: Carbamazepine $(43.2 \mu \mathrm{mol} / \mathrm{l})$

3: Internal standard

C: Cholesterol

*: 4-fold sensitivity

thus far evaluated - one may conclude that the method is highly specific, though the assessment of specificity must remain by its nature open-ended.

\section{Detectability}

The detectability was estimated by calculation of the precision of the method at low concentrations (tab. 2) (11).

\section{Comparison of the gas chromatographic procedures} and the enzyme immunoassay

\section{Carbamazepine}

\section{Criteria of reliability}

The precision of the carbamazepine determination is satisfactory for all methods, best for GC-Dexsil $300^{1}$ ),

1) Abbreviations: GC-SP 1000: Gas chromatographic procedure using SP 1000 for the determination of ethosuximide (and valproate). GC-SP $2250 \mathrm{DA}$ : Gas chromatographic procedure using SP 2250 DA for the determination of phenobarbital and phenytoin. GC-Dexsil 300: Gas chromato= graphic procedure using Dexsil-300 for the determination of carbamazepine and primidone. GC=SP 2510 DA: Gas chromatographic procedure using SP 2510 DA for the determination of carbamazepine, phenobarbital and primidone without correction by the internal standard. GC-SP 2510 DA i. st.: Gas chromatographic procedure using SP 2510 DA for the determination of carbamazepine, phenobarbital and primidone with correction by the internal standard. 
Tab. 2. Detectability. (Coefficients of variation at very low concentrations)

\begin{tabular}{|c|c|c|c|c|c|}
\hline \multirow[t]{3}{*}{ Drug } & \multicolumn{2}{|c|}{ Gas chromatography } & \multicolumn{2}{|l|}{ EMIT } & \multirow{3}{*}{$\begin{array}{l}\text { Therapeutic } \\
\text { drug } \\
\text { concentration } \\
(\mu \mathrm{mol} / \mathrm{l})(20)\end{array}$} \\
\hline & Spiked value & $\begin{array}{l}\text { Coefficient } \\
\text { of variation }\end{array}$ & Spiked value & $\begin{array}{l}\text { Coefficient } \\
\text { of variation }\end{array}$ & \\
\hline & $(\mu \mathrm{mol} / 1)$ & $\mathrm{CV}(\%)$ & $(\mu \mathrm{mol} / \mathrm{l})$ & CV $(\%)$ & \\
\hline \multicolumn{6}{|c|}{ Carbamazepine } \\
\hline $\begin{array}{l}\text { SP } 2510 \mathrm{DA} \\
\text { SP } 2510 \mathrm{DA}\end{array}$ & $\begin{array}{lr}4.2 & (9) \\
8.5 & (10)\end{array}$ & $\begin{array}{r}15.1 \\
5.5\end{array}$ & $\begin{array}{l}1.3 \quad(10) \\
4.2\end{array}$ & $\begin{array}{l}47.0 \\
<15.0^{*}\end{array}$ & $12.7-50.8$ \\
\hline \multicolumn{6}{|c|}{ Ethosuximide } \\
\hline SP 1000 & $35.4(10)$ & 10.9 & $35.4 \quad(10)$ & 7.4 & $283.3-920.7$ \\
\hline \multicolumn{6}{|c|}{ Phenobarbital } \\
\hline $\begin{array}{l}\text { SP } 2510 \mathrm{DA} \\
\text { SP } 2510 \mathrm{DA} \\
\text { SP } 2250 \mathrm{DA}\end{array}$ & $\begin{array}{rr}2.2 & (9) \\
21.5 & (10) \\
21.5 & (8)\end{array}$ & $\begin{array}{r}19.9 \\
5.7 \\
16.0\end{array}$ & $2.2(10)$ & 20.2 & $21.5-172.3$ \\
\hline \multicolumn{6}{|l|}{ Phenytoin } \\
\hline $\begin{array}{l}\text { SP } 2510 \mathrm{DA} \\
\text { SP } 2510 \mathrm{DA}\end{array}$ & $\begin{array}{r}4.0(10) \\
19.8(10)\end{array}$ & $\begin{array}{r}10.6 \\
3.0\end{array}$ & $1.2(10)$ & 19.3 & $19.8-99.1$ \\
\hline \multicolumn{6}{|l|}{ Primidone } \\
\hline $\begin{array}{l}\text { Dexsil } 300 \\
\text { Dexsil } 300\end{array}$ & $\begin{array}{ll}4.6 & (10) \\
9.2 & (10)\end{array}$ & $\begin{array}{r}10.0 \\
6.5\end{array}$ & $1.4(10)$ & 21.1 & $22.9-91.6$ \\
\hline
\end{tabular}

In brackets: number of determinations

* according to the manufacturer

bearing in mind that the EMIT assays are always based on duplicates. The deviation from the target value is small (tab. 1).

The interference by severe hemolysis is common to all EMIT assays (17) and not to the gas chromatographic procedure. But as hemolysis has no influence on the EMIT procedure presented (5) up to a hemoglobin concentration of at least $2 \mathrm{~g} / \mathrm{l}$, it is of minor importance in routine use. The carbamazepine assay (EMIT) shows a small cross-reactivity with carbamazepine-10, 11-epoxide: $64 \mu \mathrm{mol} / 1$ of this metabolite exert a change of absorbance equivalent to $11 \mu \mathrm{mol} / \mathrm{l}$ carbamazepine. As furthermore the metabolite normally represents only a small portion of carbamazepine, it does not prevent an accurate measurement. Following the original EMIT procedure, carbamazepine concentrations down to $4.2 \mu \mathrm{mol} / \mathrm{l}$ can be measured with a precision equal to that obtained with the gas chromatographic procedures. Below this concentration the imprecision of both methods rapidly increases (tab. 2).

In external quality control the values of the gas chromatographic procedure GC-SP 2510 DA and of the EMIT are compared to the mean of all participants using the enzyme immunoassay ( $t a b .3$ ). The data obtained by the GC-SP 2510 DA are more closely related to the mean of all participants using EMIT than our EMIT procedure itself. We think that this discrepancy is due to the greater imprecision of EMIT. On the other hand one may appreciate this as evidence that each method based on
Tab. 3. Carbamazepine.

External quality control of the gas chromatographic (SP 2510 DA) and the EMIT procedure.

\begin{tabular}{lllll}
\hline $\begin{array}{l}\text { Number of } \\
\text { participants }\end{array}$ & $\begin{array}{l}\text { Mean of } \\
\text { participants }\end{array}$ & $\begin{array}{l}\text { Coefficient of } \\
\text { variation (\%) } \\
\text { of participants }\end{array}$ & $\begin{array}{l}\text { Own deviation } \\
\text { from } \bar{y} \text { in \% } \\
\text { Gas chro- } \\
\text { matography }\end{array}$ & EMIT \\
$(1)$ & $\begin{array}{l}\bar{y}(\mu \mathrm{mol} / \mathrm{l}) \\
(1)\end{array}$ & $(1)$ & & \\
\hline 63 & 33.34 & 14.0 & -2.2 & +5.3 \\
77 & 13.55 & 17.3 & +6.3 & +24.7 \\
114 & 6.90 & 20.1 & -13.0 & -26.1 \\
117 & 39.80 & 15.6 & -11.8 & -5.5 \\
105 & 17.52 & 21.4 & -9.2 & -9.2 \\
116 & 11.29 & 20.4 & +1.0 & +8.9 \\
\hline
\end{tabular}

(1) related to determinations by EMIT

another principle possesses good accuracy and that the results are well comparable.

\section{Patients' sera}

Serum samples of patients treated with carbamazepine were analysed by GC-SP 2510 DA, GC-SP 2510 DA i.st. and EMIT (fig. 3). The use of the internal standard (5-(4'-methylphenyl)-5-phenylhydantoin) did not markedly improve the precision of the determination: The standard errors of estimation do not differ by more than $0.10 \mu \mathrm{mol} / 1$ (3.42 to 3.32). GC-SP $2510 \mathrm{DA}$ fits best to EMIT with no proportional error and a small intercept. 


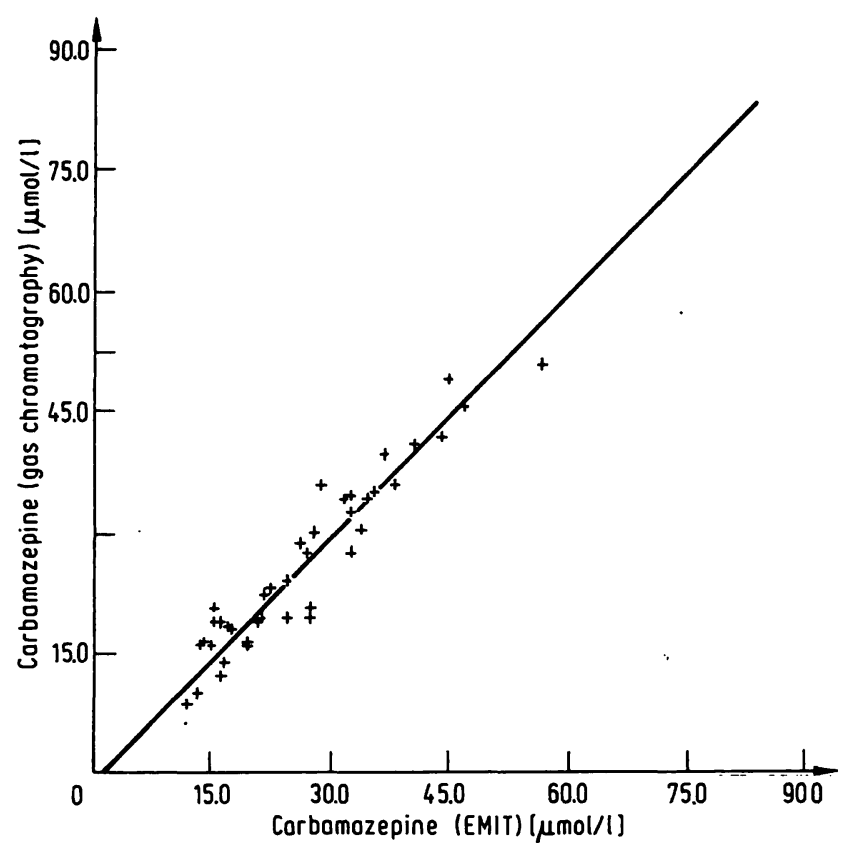

Fig. 3. Serum carbamazepine concentrations as measured by EMIT and gas chromatography (SP $2510 \mathrm{DA})(n=40)$. $y=x-0.91$ (principal component analysis $(14,15)$ ) Correlation coefficient: $\mathrm{r}=\mathbf{0 . 9 5 1}$

Standard error (16): $s_{\mathrm{y}}=3.42 \mu \mathrm{mol} / \mathrm{l}$

Mean (EMIT): $\bar{x}=26.53 \mu \mathrm{mol} / 1$

Mean (gas chromatography): $\bar{y}=25.72 \mu \mathrm{mol} / 1$

The difference between the means is not significant as calculated by the sign test $(\alpha=5 \%)(17)$.

Apparently both methods, EMIT and gas chromatography are reliable procedures for the measurement of carbamazepine.

\section{Ethosuximide}

\section{Criteria of reliability}

The precision of the ethosuximide determination by EMIT is better than expected (19) though worse than by GC-SP 1000 (tab. 1). The results differ only to a small extent from the target value. The cross-reactivity of glute thimide at (toxic) concentrations exceeding $100 \mathrm{mg} / \mathrm{l}$ and of $\mathrm{N}$-desmethylmethsuximide (19) in the EMIT assay was not observed with a gas chromatographic procedure. From the similar imprecision at small concentrations it can be judged that both methods possess similar detectability far below the therapeutic range, if the EMIT results are calculated - as in the whole study - by the empirical spline interpolation (13) (tab. 2).

In external quality control (tab. 4) our results are always within \pm one standard deviation from the mean of the corresponding gas chromatographic data, with the GC-SP 1000 data closer to the mean than the EMIT values.

The standardised principal component analysis of patients' sera analysed by GC-SP 1000 and EMIT (fig. 4) reveals a distinct proportional error that is reflected in the significant differences of the mean values. The con-
Tab. 4. Ethosuximide.

External quality control of the gas chromatographic (SP 1000) and the EMIT procedure.

\begin{tabular}{lllll}
\hline $\begin{array}{l}\text { Number } \\
\text { of par- } \\
\text { ticipants }\end{array}$ & $\begin{array}{l}\text { Mean of } \\
\text { participants }\end{array}$ & $\begin{array}{l}\text { Coefficient } \\
\text { of variation } \\
\text { (\%) of } \\
\text { participants }\end{array}$ & $\begin{array}{l}\text { Own deviation from } \bar{y} \text { in \% } \\
\text { Gas } \\
\text { chromato- } \\
\text { graphy }\end{array}$ \\
\hline $\mathrm{n}$ & $\overline{\mathrm{y}}(\mu \mathrm{mol} / \mathrm{l})$ & & \\
\hline 64 & $217.6(1)$ & $28.1(1)$ & +10.2 & +4.8 \\
74 & $407.1(2)$ & $14.5(2)$ & -1.6 & -14.3 \\
76 & $207.2(2)$ & $20.7(2)$ & +11.1 & +11.2 \\
78 & $109.9(2)$ & $27.4(2)$ & -13.9 & +8.4 \\
69 & $200.2(2)$ & $24.3(2)$ & -4.9 & not participated \\
74 & $220.6(2)$ & $19.6(2)$ & +1.7 & +4.0 \\
\hline
\end{tabular}

(1) related to determinations by EMIT

(2) related to determinations by gas chromatography (without derivative)

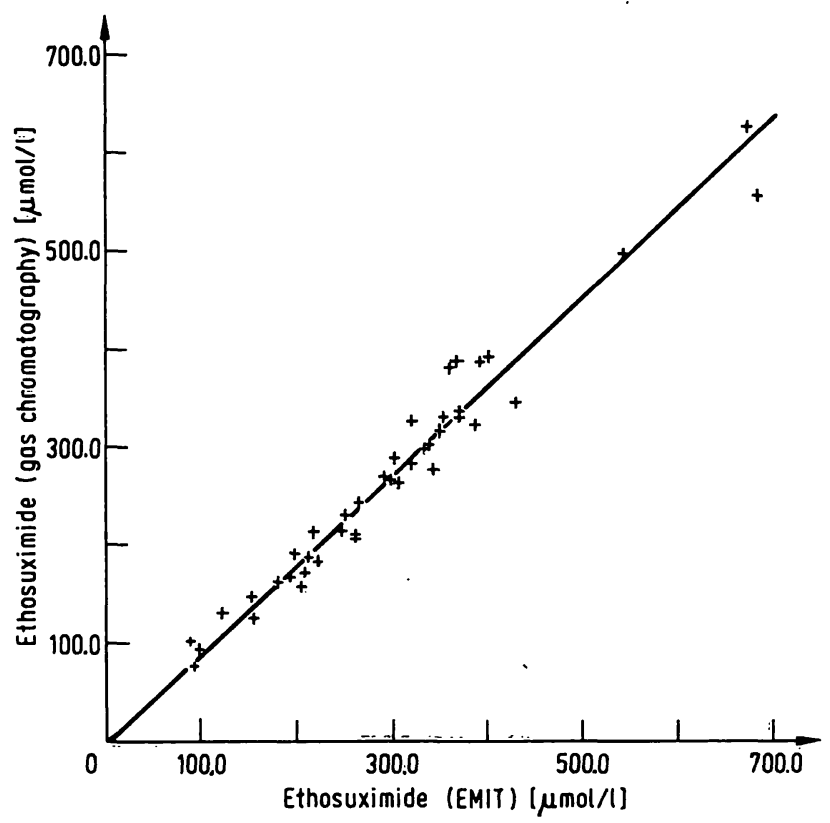

Fig. 4. Serum ethosuximide concentrations as measured by EMIT and gas chromatography (SP 1000) $(n=42)$.

$y=0.90 x-0.66$ (principal component analysis $(14,15)$ )

Correlation coefficient: $r=0.980$

Standard error (16): $s_{\mathrm{y}}=22.93 \mu \mathrm{mol} / \mathrm{l}$

Mean (EMIT): $\overline{\mathrm{x}}=297.7 \mu \mathrm{mol} / 1$

Mean (gas chromatography): $\bar{y}=268.1 \mu \mathrm{mol} / 1$

The difference between the means is significant as calculated by the sign test $(\alpha=5 \%)(17)$.

stant error is small as compared to the therapeutic range. The same is true for the standard error as a measure of random error. On the whole the differences of the values in the therapeutic range obtained by the two methods would not change the clinical interpretation.

\section{Phenobarbital}

\section{Criteria of reliability}

The precision of the methods is acceptable (tab. 1), though the coefficients of variation of EMIT are greater in spite of the use of duplicates. In GC-SP 2510 DA and EMIT the deviations from the target value are small but 
constantly positive. The enzyme immunoassay is susceptible to interference by some other barbiturates, e.g. mephobarbital $(5,17)$, but not by metabolites such as 5-ethyl-5-(4'-hydroxy-phenyl)-barbituric acid and 2-phenyl-2-ethylmalondiamide. The detectability as estimated by calculation of the precision at low concentrations is similar (tab. 2), allowing determinations below the therapeutic range. In external quality control (tab. 5) the gas chromatographic data agree well with the mean derived exclusively from determinations by EMIT, though a positive bias is obvious.

\section{Patients'sera}

Better agreement was obtained between EMIT and GC-SP 2250 DA (fig. 5), their mean values showing no significant difference, proportional and constant error being negligible, in contrast to GC-2510 DA. Nevertheless the results of the gas chromatographic methods and EMIT do not differ so much that the clinical interpretation would be altered. EMIT and GC-SP 2510 DA i.st. disagree severely: The equation of the line according to the principal component analysis: $y=1.28 x-12.83$; mean EMIT: $97.03 \mu \mathrm{mol} / 1$, mean gas chromatography: $111.71 \mu \mathrm{mol} / 1$. Obviously 5-(4'-methylphenyl)-5-phenylhydantoin is not suitable for the monitoring of phenobarbital losses during sample preparation.

\section{Pheny toin}

\section{Criteria of reliability}

According to the coefficients of variation the gas chromatographic procedures are more precise than EMIT

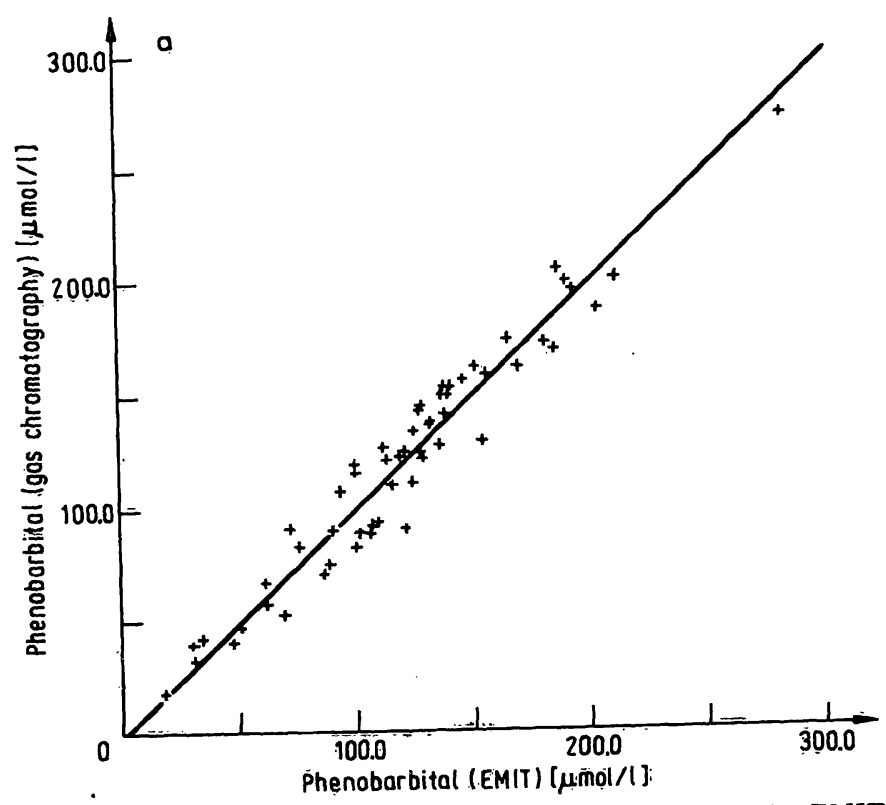

Fig. 5. Serum phenobarbital concentrations as measured by EMIT and gas chromatography

$$
\begin{aligned}
& \text { a: } S P 2250 \mathrm{DA} \\
& \mathrm{n}=57 \\
& \mathrm{y}=1.02 \mathrm{x}-2.21 \text { (principal component analysis }(14,15) \text { ) } \\
& \text { Correlation coefficient: } \tau=0.968 \\
& \text { Standard error }(16): \mathrm{S}_{\mathrm{y}}=12.81 \mu \mathrm{mol} / 1 \\
& \text { Mean (EMIT): } \overline{\mathrm{x}}=122.58 \mu \mathrm{mol} / 1 \\
& \text { Mean (gas chromatography): } \overline{\mathrm{y}}=122.53 \mu \mathrm{mol} / 1 \\
& \text { The difference between the means is not significant as } \\
& \text { calculated by the sign test }(\alpha=5 \%)(17)
\end{aligned}
$$

\begin{tabular}{|c|c|c|c|c|}
\hline \multirow{2}{*}{$\begin{array}{l}\text { Number } \\
\text { of par- } \\
\text { ticipants } \\
\mathrm{n} \\
\text { (1) }\end{array}$} & \multirow{2}{*}{$\begin{array}{l}\text { Mean of } \\
\text { participants } \\
\bar{y}(\mu \mathrm{mol} / \mathrm{l}) \\
(1)\end{array}$} & \multirow{2}{*}{$\begin{array}{l}\text { Coefficient } \\
\text { of variation } \\
\text { (\%) of } \\
\text { participants } \\
\text { (1) }\end{array}$} & \multicolumn{2}{|c|}{ Own deviation from $\bar{y}$ in \% } \\
\hline & & & $\begin{array}{l}\text { Gas } \\
\text { chromato- } \\
\text { graphy }\end{array}$ & EMIT \\
\hline $\begin{array}{r}152 \\
147 \\
88 \\
149 \\
152 \\
138 \\
105 \\
152 \\
152 \\
148 \\
147 \\
145 \\
146\end{array}$ & $\begin{array}{r}71.31 \\
318.05 \\
89.93 \\
74.15 \\
135.62 \\
71.00 \\
141.36 \\
149.12 \\
67.21 \\
181.96 \\
199.98 \\
117.36 \\
79.87\end{array}$ & $\begin{array}{l}15.6 \\
17.1 \\
14.0 \\
16.9 \\
16.4 \\
17.2 \\
16.6 \\
17.5 \\
13.7 \\
15.5 \\
16.7 \\
16.6 \\
16.7\end{array}$ & $\begin{array}{l}+7.8 \\
+\quad 7.2 \\
+\quad 0.2 \\
+13.3 \\
+23.9 \\
+\quad 1.0 \\
+\quad 1.2 \\
+10.6 \\
-\quad 4.5 \\
+10.6 \\
+9.2 \\
+2.8 \\
-10.7\end{array}$ & $\begin{array}{l}+20.9 \\
+\quad 6.8 \\
+2.5 \\
-9.9 \\
-6.3 \\
+15.4 \\
\text { not participated } \\
\text { not participated } \\
\text { not participated } \\
\text { not participated } \\
\text { not participated } \\
\text { not participated } \\
\text { not participated }\end{array}$ \\
\hline
\end{tabular}

Tab. 5. Phenobarbital.

External quality control of the gas chromatographic (SP 2510 DA) and the EMIT procedure.

(1) related to determinations by EMIT

(tab. 1). Cross-reactivity for the EMIT assay is described for ethotoin $(>200 \mathrm{mg} / 1)$, 5-ethyl-5-phenylhydantoin (>100 mg/l), 5-(4'-hydroxyphenyl)-5-phenylhydantoin $(>8 \mathrm{mg} / \mathrm{l})$ and mepheny toin $(>100 \mathrm{mg} / \mathrm{l})(5,17)$.

Among the drugs tested no compound was found that interferes with the gas chromatographic determination. All the methods allow the measurement of phenytoin concentrations below the therapeutic range, though

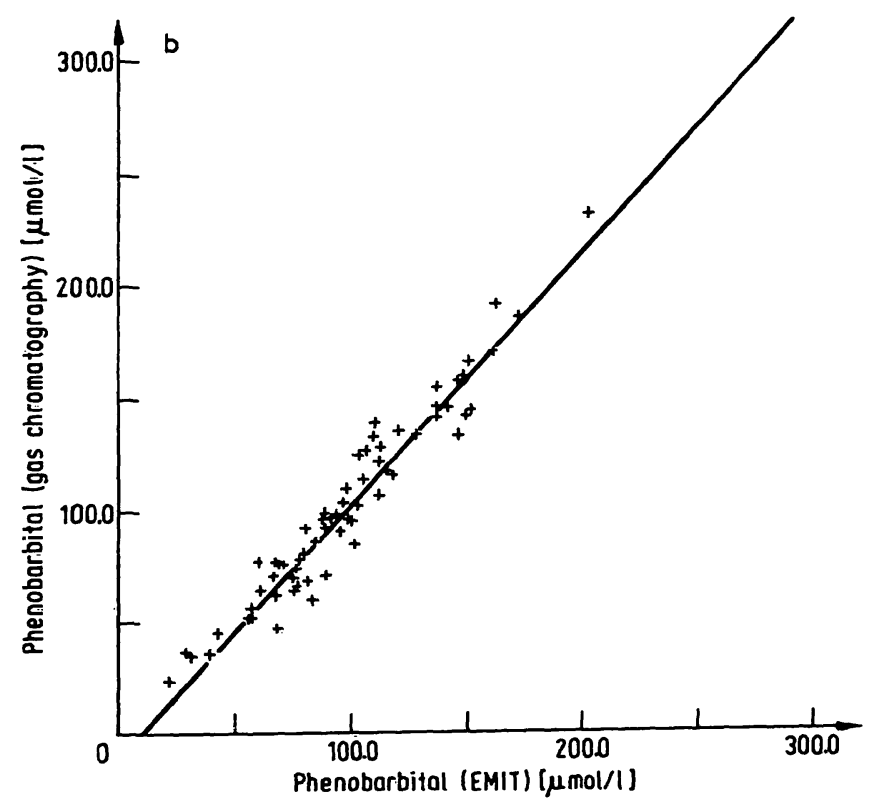

b: SP $2510 \mathrm{DA}$

$\mathrm{n}=68$

$\mathrm{n}=68$
$\mathrm{y}=1.15 \mathrm{x}-10.72$ (principal component analysis $(14,15)$ )

Correlation coefficient: $r=0.970$

Standard error (16): $s_{\mathrm{y}}=6.94 \mu \mathrm{mol} / \mathrm{l}$

Mean (EMIT): $\bar{x}=97.03 \mu \mathrm{mol} / 1$

Mean (gas chromatography): $\overline{\mathrm{y}}=101.25 \mu \mathrm{mol} / \mathrm{l}$

The difference between the means is significant as calculated by the sign test $(\alpha=5 \%)(17)$ 
EMIT seems to be more sensitive (tab. 2), if the empirical spline interpolation is used for calculation. The reason may be the flat peaks of phenytoin eluted as the last drug.

In external quality control (tab. 6) the results of the gas chromatographic and the EMIT procedure are compared to the mean of enzyme immunoassays. Because of their better precision the gas chromatographic data are more closely related to the mean than the EMIT values, both with a slightly negative bias.

\section{Patients'sera}

The agreement between GC-SP 2510 DA and EMIT for patients' sera is good, showing only a small proportional and a small constant error (fig. 6). The mean values do not differ significantly and random error is acceptable. The use of the internal standard for the calculation of the results slightly improved reliability.

\section{Primid one}

\section{Criteria of reliability}

Because of the interference of cholesterol on SP 2510 DA, primidone could only be measured using Dexsil 300 (11). The gas chromatographic procedure seems to be less precise than EMIT with a small positive bias (tab. 1). Of the drugs so far tested none interfered with the gas chromatographic determination (11). EMIT shows crossreactivity with 2-phenyl-2-ethylmalondiamide only at extremely high concentrations $(>500 \mathrm{mg} / \mathrm{l})(19)$. Both methods allow precise determinations in the subtherapeutic range (tab. 2).

The comparison of results from patients'sera (fig. 7) reveals a distinct proportional error, which leads to a significant difference of the mean values, but not to a different interpretation by the clinicians.

Tab. 6. Phenytoin.

External quality control of the gas chromatographic (SP 2510 DA) and the EMIT procedure.

\begin{tabular}{|c|c|c|c|c|}
\hline \multirow{2}{*}{$\begin{array}{l}\text { Number of } \\
\text { participants } \\
\mathrm{n} \\
\text { (1) }\end{array}$} & \multirow{2}{*}{$\begin{array}{l}\text { Mean of } \\
\text { participants } \\
\bar{y}(\mu \mathrm{mol} / \mathrm{l}) \\
(1)\end{array}$} & \multirow{2}{*}{$\begin{array}{l}\text { Coefficient of } \\
\text { variation (\%) } \\
\text { of participants } \\
\text { (1) }\end{array}$} & \multicolumn{2}{|c|}{$\begin{array}{l}\text { Own deviation } \\
\text { from } \bar{y} \text { in } \%\end{array}$} \\
\hline & & & $\begin{array}{l}\text { Gas chro- } \\
\text { matography }\end{array}$ & EMIT \\
\hline 97 & 83.56 & 11.4 & +5.7 & -1.4 \\
\hline 146 & 51.9 & 12.7 & -12.5 & -21.5 \\
\hline 160 & 54.52 & 13.4 & +8.0 & -5.5 \\
\hline 154 & 38.92 & 17.3 & +4.6 & +12.0 \\
\hline 154 & 77.01 & 15.4 & -13.4 & -15.2 \\
\hline 109 & 37.38 & 16.2 & +4.9 & -4.8 \\
\hline 158 & 69.32 & 12.6 & -3.3 & +8.4 \\
\hline 157 & 25.51 & 18.0 & -14.5 & -0.8 \\
\hline 151 & 58.14 & 10.6 & -2.6 & +7.7 \\
\hline 156 & 30.03 & 16.6 & +3.9 & -9.1 \\
\hline 159 & 62.64 & 16.0 & +6.2 & -2.0 \\
\hline
\end{tabular}

(1) related to determinations by EMIT

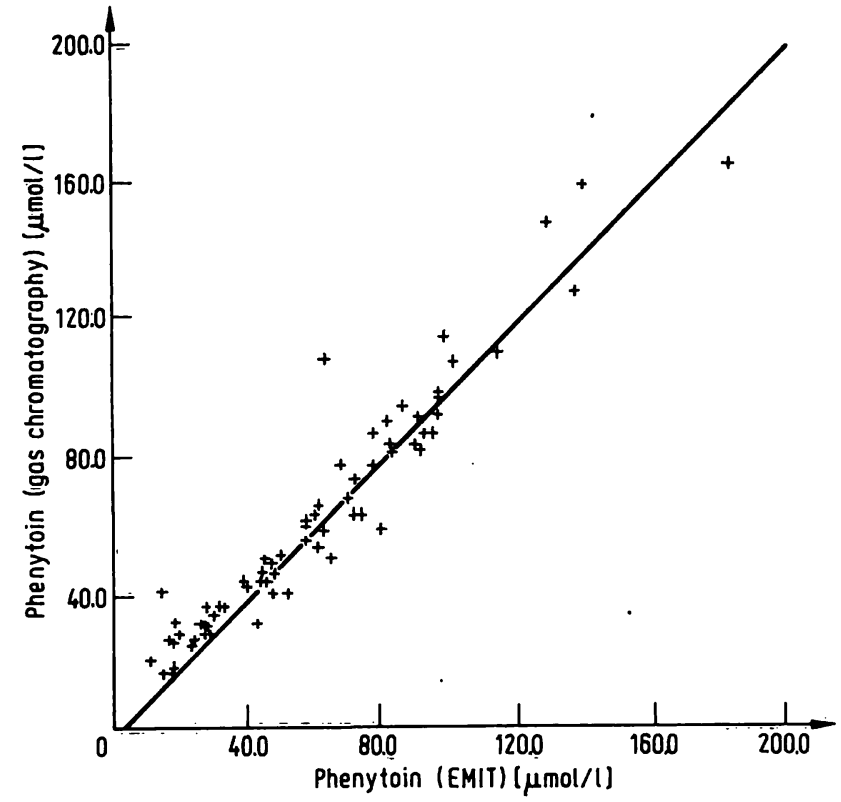

Fig. 6. Serum pheny toin concentrations as measured by EMIT and gas chromatography (SP $2510 \mathrm{DA})(\mathrm{n}=70)$. $y=0.98 x-2.00$ (principal component analysis $(14,15)$ ) Correlation coefficient: $r=0.959$ Standard error (16): $9.65 \mu \mathrm{mol} / 1$ Mean (EMIT): $\bar{x}=60.02 \mu \mathrm{mol} / 1$ Mean (gas chromatography): $\bar{y} \equiv 60.52 \mu \mathrm{mol} / \mathrm{l}$ The difference between the means is not significant as calculated by the sign test $(\alpha=5 \%)$ (17).

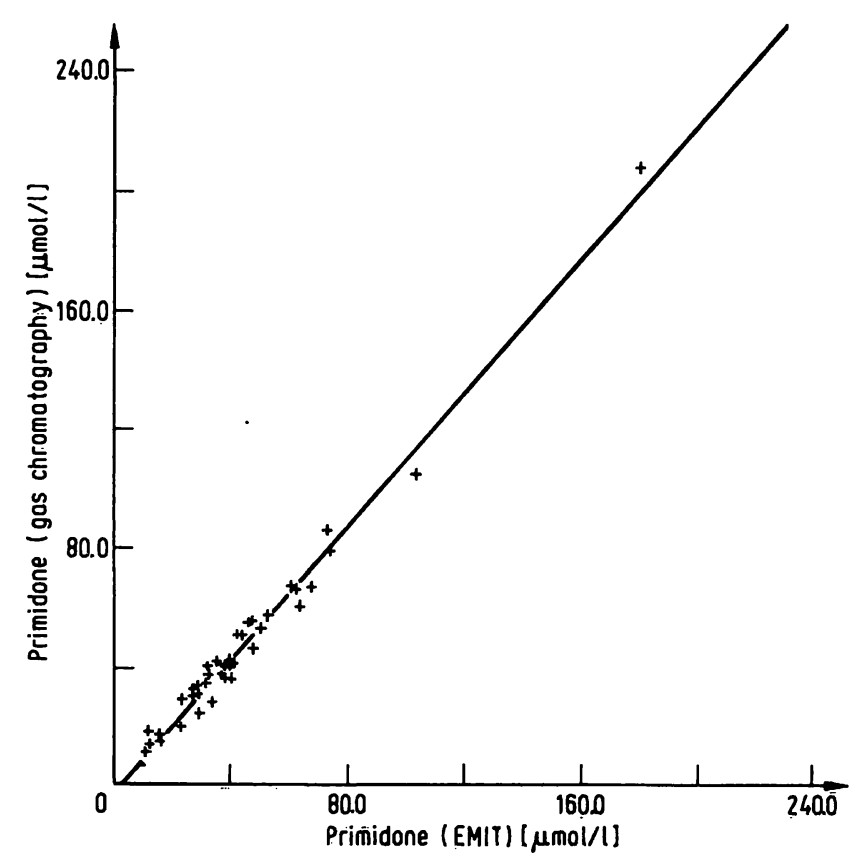

Fig. 7. Serum primidone concentrations as measured by EMIT and gas chromatography (Dexsil 300) $(n=42)$. $y=1.13 x-2.75$ (principal component analysis $(14,15)$ ) Correlation coefficient: $r=0.990$ Standard error (16): $s_{\mathrm{y}}=4.60 \mu \mathrm{mol} / \mathrm{l}$ Mean (EMIT): $\bar{x}=43.11 \mu \mathrm{mol} / 1$ Mean (gas chromatography): $\bar{y}=45.95 \mu \mathrm{mol} / \mathrm{l}$ The difference between the means is significant as calculated by the sign test $(\alpha=5 \%)(17)$. 
Tab. 7. Primidone.

External quality control of the gas chromatographic (Dexsil 300) and the EMIT procedure.

\begin{tabular}{lllll}
\hline $\begin{array}{l}\text { Number of } \\
\text { participants }\end{array}$ & $\begin{array}{l}\text { Mean of } \\
\text { participants }\end{array}$ & $\begin{array}{l}\text { Coefficient } \\
\text { of variation } \\
\text { (\%) of par- } \\
\text { ticipants }\end{array}$ & $\begin{array}{l}\text { Own deviation } \\
\text { from } \bar{y} \text { in \% } \\
\text { Gas chro- } \\
\text { matography }\end{array}$ & EMIT \\
$\mathrm{n}$ & $\begin{array}{l}\bar{y}(\mu \mathrm{mol} / \mathrm{l}) \\
(1)\end{array}$ & (1) & & \\
\hline 87 & 67.50 & 14.7 & +1.6 & +14.7 \\
101 & 69.29 & 14.5 & -1.0 & -10.8 \\
95 & 16.76 & 23.7 & not participated -18.3 \\
92 & 13.69 & 20.8 & -18.2 & -2.8 \\
\hline
\end{tabular}

(1) related to determinations by EMIT

The few results obtained in external quality control (tab. 7) may demonstrate at best an acceptable agreement of both methods with the mean of all EMIT assays.

\section{Practicability}

A major advantage of EMIT is its quick performance. 30 samples can be measured within 60 minutes if on line data processing is possible (5). The gas chromatographic procedure requires 15 hours for the same number of analyses. But an equally mechanized gas chromatograph may run this number of determinations automatically without personnel guidance thereby, sparing 12 hours of technician time, if a method is available that allows the determination of antiepileptic drugs without derivatisation under isothermal conditions. If, in addition, carbamazepine, phenobarbital and phenytoin are measured simultaneously, the number of analyses is reduced by $15 \%$ according to our statistics. If primidone can be included by use of an alkali flame ionisation detector, the reduction is $32 \%$. If a single sample must be urgently processed, analysis by EMIT will take 15-40 min depending on one's instrumentation, whereas determination by the gas chromatographic procedure will be accomplished within 2 hours.

The cost of a single analysis by EMIT using the Eppendorf 5010 is high and was calculated to be 53 US\$ for pheny toin (0.30 US $\$$ per minute effective working time of the technicians). It may be reduced, if an ACA (Automatic Clinical Analyzer, Du Pont de Nemours) is available (24 U.S\$). A single determination by gas chromatography calculated under the same assumptions will cost 37 ÜS\$.

A series of 20 samples analysed by EMIT will cost 7 US $\$$ per sample using the Eppendorf 5010 and 14 US \$ per sample using the gas chromatographic procedure. Money can be spared in the case of EMIT, especially if the volume of the (expensive) reagents needed can be reduced, and in the case of gas chromatography, if mechanized instruments are available that run the analyses unattended by the technicians.

In contrast to EMIT the reagents in gas chromatography are stable and easily available from many manufacturers. The apparatus used for EMIT is very often already at hand in the laboratory and can be used for other routine work, because of the short time necessary in photometry. A gas chromatograph will not be available in many laboratories for clinical chemistry. The time for a determination is rather long and a comparably small workload can be run on one instrument. On the other hand gas chromatography gives access to the determination of many other drugs for which an EMIT is not available.

\section{Conclusion}

Among the stationary phases tested we prefer on the whole SP 2510 DA for the measurement of carbamazepine, phenobarbital and phenytoin, because of its reliability and practicability. It can be expected that as soon as we have an alkali flame ionisation detector primidone will be included. Hewitt et al. (2) separate interfering cholesterol during extraction, but the recovery of primidone is poor (69\%). Godolphin et al. (1) use a precolumn of SP 2250 DA for the same purpose, but this stationary phase is not well suited for the gas chromatography of carbamazepine and primidone. The use of the internal standard did not markedly improve the results. Obviously there is not yet an internal standard equally suited for all compounds.

The reliability of EMIT is acceptable, though on the whole somewhat lower than that of the gas chromatographic procedures. Interferences by drugs cannot easily be detected. But the experimental data and experience from routine use show that inaccuracy due to unspecificity is rare in the EMIT assay for antiepileptic drugs.

The results of GC-SP 2510 DA are generally best comparable to those obtained by EMIT with the exception of phenobarbital that behaves better on GC-SP 2250 DA.

Although small, but significant differences were found between gas chromatography and EMIT in the determination of ethosuximide, phenobarbital and primidone, indicating an inaccuracy of one or both methods, the results are sufficiently similar for the methods to be interchangeable for their intended use in therapeutic drug monitoring. As far as practicability is concerned it may be advantageous that the reagents for gas chromatography are stable, cheap and freely available from many manufacturers. Because of its flexibility gas chromatography may be easily adapted to the measurement of many drugs of perhaps current interest, whereas determinations by EMIT will include always, only a rather limited number of substances and the development of new tests is time-consuming. 


\section{References}

1. Godolphin, W. \& Thoma, J. (1978), Clin. Chem. 24, 483485.

2. Hewitt, T. E., Sievers, D. L. \& Kessler, G. (1978), Clin. Chem. $24,1854-1856$.

3. Dijkhuis, I. C.. De Jong, H. J., Richens, A., Pippenger, C. E., Leskinen, E. A. \& Nyberg, A. P. W. (1979), Pharm. Weekbl. Sci. Ed. 1, 151-184.

4. Legaz, M. \& Raisys, V. A. (1976), Clin. Biochem. 9, 35-38.

5. Oellerich, M., Külpmann, W. R., Haeckel, R. \& Heyer, R. (1977), J. Clin. Chem. Clin. Biochem. 15, 353-358.

6. Schmidt, D., Goldberg, V., Guelen, P. J. M., Johannessen, S., v. d. Kleijn, E., Meijer, J. W. A., Meinardi, H., Richens, A., Schneider, H., Stein-Lavie, Y. \& Symann-Louette, N. (1977), Epilepsia 18, 367-374.

7. Sun, L. \& Szafir, J. (1977), Clin. Chem. 23, 1753-1756.

8. Chamberlain, R. T., Stafford, D. T., Maijub, A. G. \& McNatt, B. C. (1977), Clin. Chem. 23, 1764-1766.

9. Kumps, A., Mardens, Y.. Scharpé, S. \& Verkerk,·R. (1978), in Enzyme labelled immunoassay of hormone and drugs (Pal, S. B., ed.), 405-408, de Gruyter, Berlin-New York.
10. Nandekaar, A. K. N., Kutt, H. \& Fairclough, G. F. jr. (1978), Clin. Toxicol. 12, 483-494.

11. Külpmann, W. R. (1980), J. Clin. Chem. Clin. Biochem. (1980), 18, 227-232.

12. Külpmann, W. R. (1980), J. Clin. Chem. Clin. Biochem. (1980), 18, 339-344.

13. Porth, A. \& Oellerich, M. (1981), in preparation.

14. Anderson, T. W. (1958), An introduction to multivariate statistical analyses, J. Wiley, New York.

15. Feldmann, U., Schneider, B. \& Haeckel, R. (1981), in preparation.

16. Westgard, J. O. \& Hunt, M. R. (1973), Clin. Chem. 19, 49-57.

17. Gindler, E. M. (1975), Clin. Chem. 21, 309-314.

18. Copeland, B. E. (1957), Am. J. Clin. Pathol. 27, 551-558.

19. Anonymous, Emit - aed, Syva, Palo Alto.

20. Schmidt, D. (1977), Therapiewoche $27,501-510$.

Priv.-Doz. Dr. W. R. Külpmann Institut für Klinische Chemie Karl-Wiechert-Allee 9 D-3000 Hannover 61 